\title{
Fen Bilimleri Öğretmenlerinin Genetiği Değiştirilmiş Organizmalar Hakkındaki Görüşlerinin Belirlenmesi
}

\author{
${ }^{1}$ Aslı GÖRGÜLÜ ARI ve ${ }^{* 2}$ Kevser ARSLAN \\ ${ }^{1}$ Eğitim Fakültesi, Matematik ve Fen Bilimleri Eğitimi Bölümü, Yıldız Teknik Üniversitesi, Türkiye \\ *2Fen Bimleri Enstitüsü Yıldız Teknik Üniversitesi, Türkiye
}

\begin{abstract}
Özet
$\mathrm{Bu}$ araştırmada, fen bilimleri öğretmenlerinin genetiği değiştirilmiş organizmalar (GDO) hakkındaki görüşlerinin belirlenmesi amaçlanmıştır. Araştırma yöntemlerinden betimsel tarama modeli kullanılmıştır. Araştırmanın çalışma grubunu İstanbul'da devlet okulu ve özel okullarda öğretmenlik yapan 26 adet fen bilimleri öğretmeni oluşturmaktadır. Öğretmenlerin GDO’lu ürünlere yönelik görüşlerinin belirlenmesi amacıyla, 7 adet açık uçlu sorudan oluşan ölçme aracı kullanılmıştır. Veri toplama aşaması, öğretmenlere herhangi bir müdahalede bulunulmadan tek aşamada gerçekleştirilmiş, açık uçlu sorular yardımıyla öğretmenlerin yazılı cevapları alınmıştır. Elde edilen verilerin analizinde nitel araştırma tekniklerinden içerik analizi kullanılmıştır. Temalar ve kodlar oluşturularak frekans değerleri hesaplanmıştır. Araştırmanın güvenirliliği sağlamak için veriler bir alan uzmanı tarafından da incelenmiş ve güvenirlik hesaplaması Miles ve Huberman'ın (1994) güvenirlik formülü kullanılarak gerçekleştirilmiştir. Araştırmada öğretmenlerin GDO’nun tanımına yönelik bilgilere sahip oldukları, GDO’lu ürünlere karşı olumsuz düşünceler oluşturduklarını ve çocuk beslenmesini olumsuz etkilediği yönünde görüş belirttiği sonucuna ulaşılmış ve konu hakkında önerilerde bulunulmuştur.
\end{abstract}

Key words: Genetiği Değiştirilmiş Organizmalar, Sosyobilimsel Konular, Fen Bilimleri Öğretmenleri

\begin{abstract}
In this study, it was aimed to determine the opinions of science teachers about genetically modified products (GMO). A descriptive survey model was used. The study group consists of 26 science teachers who teach in public schools and private schools in Istanbul. 7 open-ended questions were prepared to determine the opinions of teachers about GMO products. The data collection phase was carried out in a single stage without any intervention by the teachers and the written answers of the teachers were taken with the help of open-ended questions. In the analysis of the data, content analysis was used from qualitative research techniques. Frequency values were calculated by creating themes and codes. In order to ensure the reliability of the study, data were also examined by a field expert and reliability calculation was performed by using Miles and Huberman's (1994) reliability formula. In the study, it was concluded that the teachers have information about the definition of GMOs, that they create negative thoughts against GMOs and that they negatively affect child nutrition were determined and recommendations were made.
\end{abstract}

Key words: Genetically Modified Organisms, Socio-Scientific Subjects, Science Teachers

\section{Giriş}

Dünya nüfusunun artışa geçmesiyle birlikte mevcut besin kaynaklarının çeşitlendirilmesi ve çoğaltılması ihtiyacı doğurmuştur [1]. Bu ihitiyaçtan yola çıkılarak besinlerin daha verimli ve daha fazla miktarda, uzun ömürlü eldesi önemli bir araştırma alanı olmuştur. Bundan sonraki süreçte olağanüstü bir şekilde ilerleme gösteren gen teknolojisi yalnız bir araştırma sahası olmaktan sıyrılıp, besin teknolojisi gibi birçok alanda gündelik yaşantımıza dâhil olmuştur. Gen

*Kevser Arslan: Adres: Eğitim Fakültesi, Fen Bilgisi Eğitimi Bölümü Yıldız Teknik Üniversitesi, İstanbul Türkiye. E-mail adresi: arslankevser96@gmail.com doi: 10.33793/acperpro.02.01.4 
teknolojisinin en çok konuşulan konularından biri olan genetiği değiştirilmiş organizmalar (GDO) tüm dünya gündeminin merkezine oturmuştur [2]. GDO'lu ürünlerin olumlu ve olumsuz yönleri bilim insanlarının farklı görüşlerde bulunduğu ve kendi aralarında ortak bir yargıya varamadıkları, genel olarak ahlaki ve etik bir muhakeme gerektiren sosyobilimsel bir konu olarak halen tartışılmaya devam etmektedir. Sosyobilimsel konuların öğretimi, modern fen eğitiminin son derece önemli hedeflerinden birisidir[4].Bu doğrultuda birçok kurum ve kuruluş sosyobilimsel konuların öğretim programında yer verilmesini, tartışılmasını ve analizinin yapılmasını vurgulamıştır[3,5].Bu konuların ülkemizde fen eğitimi içerisinde yer almaya başlanmasıyla beraber, öğretim programında yer almıştır. Sosyobilimsel konulara odaklanan öğretim yaklaşımının veya modelinin fen bilimleri dersinde kullanılması öğretim programının amacına son derece fayda sağlaması beklenmektedir. Sosyobilimsel konuları temel alan öğrenme ortamlarının, öğrencilere fen kavramlarının öğretilmesinde etkili olduğu [6], öğrenmeyi dikkat çekici hale getirdiği[7], ve öğrencilerin fen dersine olumlu tutum geliştirdiği [8] yönünde sonuçlara varılmıştır. Öğrencilerin bu tür konulardaki gelişimlerine ilişkin bilgiye sahip fertler olmalarında ilköğretimden yükseköğretime farklı kademelerde görevli fen eğitimcilerine önemli görevler düşmektedir[9].Literatür incelendiğinde GDO ve GDO'lu ürünler konusunda gerçekleştirilmiş olan çalışmalara rastlamak mümkündür. İlköğretim öğrencileri üzerinde gerçekleştirilmiş olan bir çalışmada 8.sınıf öğrencilerinin GDO hakkındaki bilgi düzeyleri ve biyoteknolojiye yönelik tutumları tespit edilirken [10]; diğer bir çalışmada okul dışı öğrenme ortamlarında yürütülen etkinliklerin öğrencilerin sosyobilimsel konular ilişkin görüşlerine etkisini belirlenmeye çalışılmıştır [11]. Bu konu kapsamında öğretmenlere yönelik yapılmış çalışmalar da mevcuttur. Bir çalışmada fen alanlarında (biyoloji, fizik, kimya ve fen bilgisi) öğrenim gören öğretmenlerin GDO’ya ilişkin metaforlarının ve görsel imajlarının belirlenmesinin amaçlanırken [12]; başka bir çalışmada Eğitim Fakültesi Sınıf Öğretmenliği programında okuyan adayların GDO’ya ilişkin algıları metaforlar aracılığıyla analiz edilmeye çalışılmıştır [13].

Fen Bilimleri dersi ve öğretmenleri açısında GDO konusunun önemi ve geleceğe yönelik faydaları düşünüldügünde, bu konuda yapılan çalışmaların alan yazın yönünden gerekli olduğu açıktır. Fen bilimleri öğretmenlerinin sosyobilimsel konulardan biri olan GDO'lu ürünler hakkındaki bilgi düzeyleri ve görüşlerinin belirlenmesi gelecek neslin, sağlıklı yaşam ve sağlıklı beslenmeleri açısından oldukça önemlidir. Bu gereklilik doğrultusunda yapılan bu araştırmada, Fen Bilimleri öğretmenlerinin GDO’lu ürünler hakkındaki görüşlerinin belirlenmesi amaçlanmaktadır.

\section{Yöntem}

\subsection{Araştırma Modeli}

Araştırmada nitel araştırma teknikleri kullanılmıştır.Araştırma da nitel araştırma desenlerinden betimsel tarama yöntemi tercih edilmiştir. Tarama yöntemi, geçmişte ya da halen var olan bir durumun olduğu şekliyle betimlenmesini amaçlayan bir yaklaşımdır [14].Betimsel çalışmalar aracılığıyla çalışılmakta olan olguya dair fertlerin tutum, görüş veya davranışlarının ortaya çıkarılması amaçlanmaktadır [15].

\section{2. Çalışma Grubu}

Araştırmanın çalışma grubunu İstanbul'da devlet okulu ve özel okullarda görev yapan 26 adet fen bilimleri öğretmeni oluşturmaktadır. Örneklemin belirlenmesinde kolay ulaşılabilir 
durum örneklemesine başvurulmuştur. Kolay ulaşılabilir durum örneklenmesinde, örneklem araştırmacının çalışmasını yürütmesi için uygun özelliktedir ve bu örnekleme ulaşmak kolaydır. Örneklem rastgele ya da sistematik olarak seçilemediği durumlarda tercih edilebilir [16].

\subsection{Veri Toplama Araçları}

Araştırmada veri toplama aracı olarak 7 adet açık uçlu sorudan oluşan ölçme aracı kullanılmıştır. Açık uçlu sorular Glazar ve Vrtacnik'in belirttiği gibi, öğrencinin düşünme sürecini keşfetmeyi ve kavramları nasıl anladığı hakkında daha derin bir görüşe sahip olmayı sağlar [17]. Açık uçlu sorular; bireylerin deneyim, fikir ve duygularını tanımlarken kullandıkları tema, imge ve kelimeleri inceleme firsatı sunması açısından oldukça önemlidir [18]. Fen bilimleri öğretmenlerin GDO'lu ürünlere yönelik görüşlerini belirlemeye yönelik hazırlanan 7 tane açık uçlu soru iki alan uzmanı tarafından incelendikten sonra iki öğretmene okutulmuş, anlaşılırlığı tespit edilmiştir.

\subsection{Uygulama Süreci}

Uygulama aşamasında, Fen Bilimleri öğretmenlerine GDO’lu ürünlere yönelik hazırlanmış olan 7 adet açık uçlu sorudan oluşan ölçme aracı dağıtılmış ve doldurmaları istenmiştir. Öğretmenlere hiçbir müdahalede bulunulmadan yaklaşık bir saat içinde uygulama işlemi gerçekleştirilmiştir.

\subsection{Verilerin Çözümlenmesi}

Araştırmada GDO'lu ürünlere yönelik hazırlanan ölçme aracından elde edilen verilerin analizinde nitel araştırma tekniklerinden içerik analizine başvurulmuştur. İçerik analizi ile veri toplama süreci sonunda elde edilen çok sayıdaki bilginin başlıca anlamlı bölümleri belirlenir, her bölümün kavramsal olarak ne anlam ifade ettiği belirlenir, oluşturulan bölümler için kodlamalar yapılır ve kodlar belirli kategoriler altında toplanarak temalar oluşturulur [19]. Her soru ve yanıtları için tablolar oluşturulmuştur. Verilen cevaplar kod adı altında yazılarak farklı temalar altına yerleştirilmiştir. Her kod için ayrı frekans değerleri oluşturulmuştur. Oluşturulan kodlar tekrar gözden geçirilmiş, düzenlenmiş ve uygun temalar elde edilmiştir. Sorularda öğretmenlerin GDO’lu ürünlere yönelik tanımlamaları, genetiği değiştirilmiş ürünlere karşı olumlu olumsuz algıları, çocuk beslenmesinde bu tür ürünlerin etkileri, satın alınan ürünlerde GDO'lu katkıların belirtilme düzeylerine dikkatleri, ülkemizdeki serbestlik durumuna ve yasal düzenlemesine dair fikirleri belirlenmeye çalışılmıştır.

\subsection{Güvenilirlik}

Güvenirliliği sağlamak adına veriler bir alan uzmanı tarafından da incelenmiş ve oluşturulan tema ile kodlar arasında uzlaşı olup olmadığına bakılmıştır. Farklı araştırmacıların aynı verileri yorumlayarak kodlar ve temalar oluşturulması ve bunların kıyaslanması güvenirliğin sağlanması açısından önemlidir [20,21] ve aynı zamanda araştırmacının katılımcılar ile uzun süreli etkileşim içerisine girmesi inandırıcılığ artıran bir başka göstergedir [19]. Oluşturulan temalar için güvenirlik hesaplaması Miles ve Huberman'ın (1994) güvenirlik formülü kullanılarak hesaplanmıştır. Güvenirlik kat sayısı fikir birliği bulunanların, fikir birliği bulunan ve fikir birliği bulunmayanların toplamına bölünüp 100 ile çarpılmasıyla hesaplanır. Değerin en az 80 olması gerekmektedir [22]. Nitel veri kaynaklarından elde edilen kodlara yönelik 
güvenilirlik kat sayısı Tablo 1'de verilmiştir. Ölçme aracından elde edilen kodlar için güvenirlilik kat sayısı 89 olarak hesaplanmıştır.

Tablo 1. Güvenirlik Değeri

Nitel Veri Kaynakları

Güvenirlik Değeri \%

Açık Uçlu Ölçme Aracı

89

\section{BÖLÜM III: BULGULAR}

\subsection{Nitel Verilere İlişskin Bulgular}

Araştırma kapsamında sorulan sorulardan elde edilen bulgular tablolar halinde aşağıda verilmiştir.

Tablo 2. GDO’lu Ürünlerin Tanımına İlişskin Fen Bilimleri Öğretmenlerinden Elde Edilen Veriler

\begin{tabular}{|c|c|c|}
\hline TEMA & KOD & FREKANS \\
\hline \multirow[b]{2}{*}{ GENETIKK DİZILİM } & Genetiği değiştirilmiş organizmalar & 20 \\
\hline & $\begin{array}{l}\text { Aşılama, ilaçlama gibi yöntemler kullanılarak genetik yapının } \\
\text { değiştirilmesi, doğal şartların dışına çıkılması }\end{array}$ & 2 \\
\hline \multirow{6}{*}{ ÜRÜN NITELİĞİ } & Uzun ömürlü yiyecekler oluşturmak için yapılan uygulamalar & 4 \\
\hline & Dayanıklılık ve ilgi için yapılan uygulamalar & 3 \\
\hline & İstenilen standartlarda ürün elde edilebilmesi & 3 \\
\hline & Besinlerin lezzetini arttırmak için yapılan uygulamalar & 2 \\
\hline & Ürünlerin kalitesini arttırmak için yapılan uygulamalar & 2 \\
\hline & Ürünlere farklı özellikler aktarmak için yapılan uygulamalar & 1 \\
\hline \multirow{3}{*}{ ÜRÜN VERIMII } & Ürünlerin miktarını arttırmak için yapılan uygulamalar & 2 \\
\hline & Üreme hızlarının ve saklanma koşullarının iyileştirmek & 1 \\
\hline & Besinin büyümesi içi dışarıdan yapılan etkiler & 1 \\
\hline \multicolumn{3}{|c|}{$\begin{array}{l}\text { Tablo 2'de görüldüğ̈̈ üzere öğretmenlerin GDO’lu ürünlere dair tanımları,"Genetik Dizilim", } \\
\text { "Ürün Niteliği" ve "Ürün Verimi" olmak üzere üç tema altında toplanmıştır. Öğretmenlerin büyük } \\
\text { bir çoğunluğunun bu kavramın tanımını doğru bildiği görülmektedir. Ayrıca öğretmenlerin bu } \\
\text { ürünlerin oluşturulmasında istenilen standartlarda ve özelliklerde besinler elde edilmesi amacıyla } \\
\text { ürünlerin nitelikleri üzerinde değişiklikler yapıldığını belirtmişlerdir. Buna ek olarak da ürünlerin } \\
\text { üreme hızını ve miktarını arttırmak amacıyla da ürünlerin verimi üzerinde yaplan değişiklikler } \\
\text { olduğunu da belirtmişlerdir. }\end{array}$} \\
\hline
\end{tabular}

Tablo 3. GDO’lu Ürünlerin Neler Olabileceğine İlişkin Fen Bilimleri Öğretmenlerinden Elde Edilen Veriler 


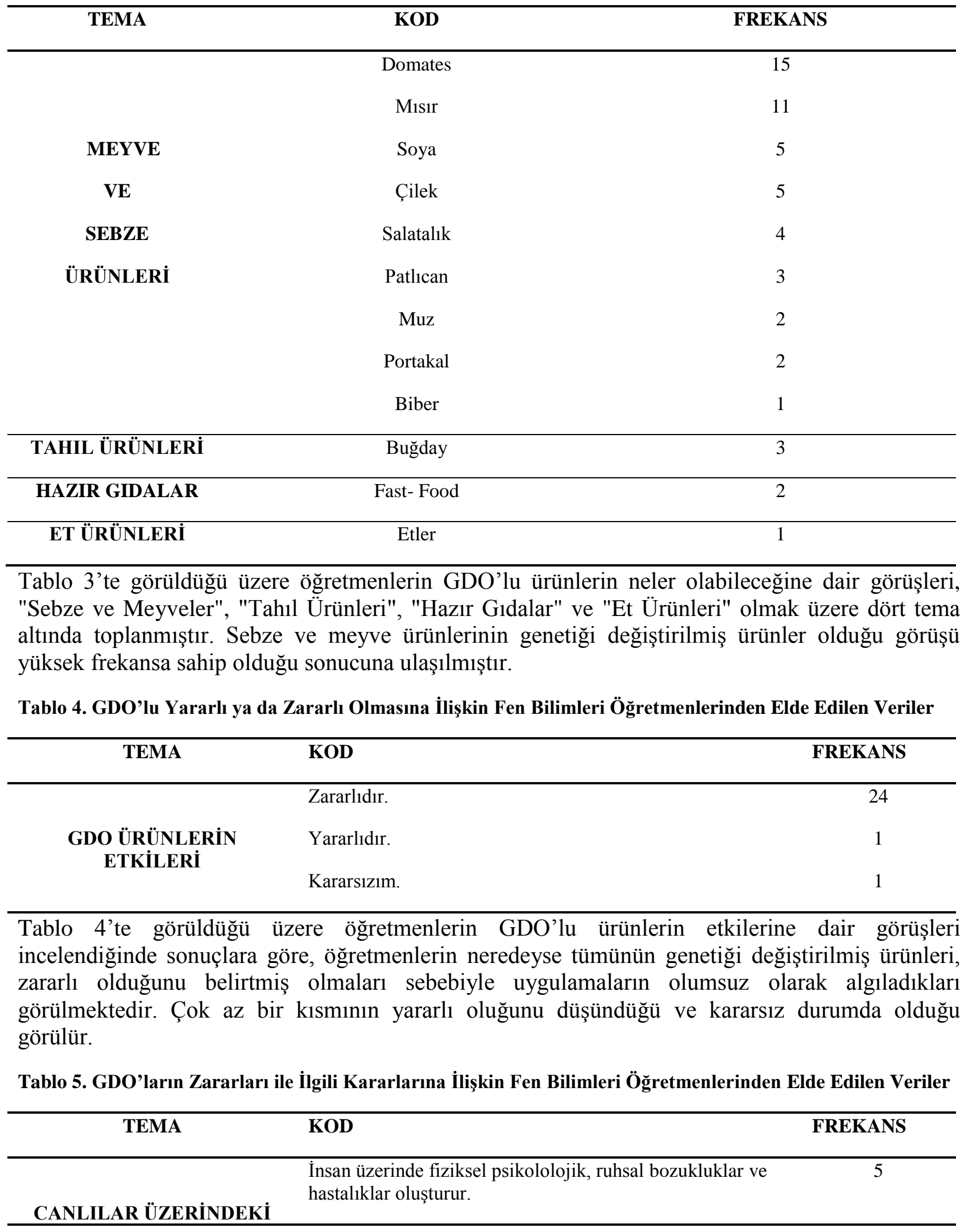




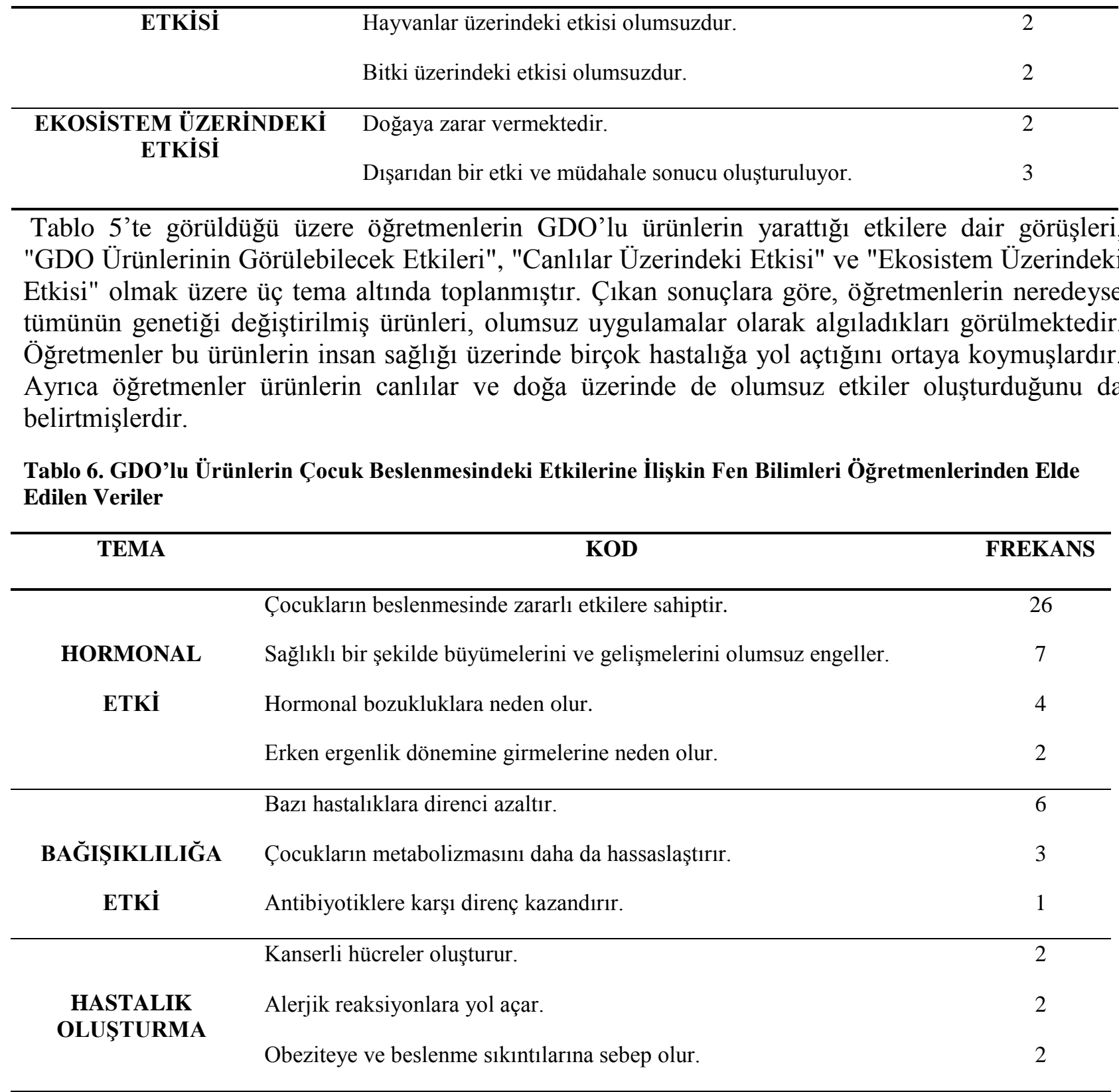

Tablo 6'da görüldüğü üzere öğretmenlerin GDO'lu ürünlerin çocuk beslenmesindeki etkilerine dair görüşleri; "Hormonal Etki", "Bağışıklılığa Etki" ve "Hastalık Oluşturma" olmak üzere üç tema altında toplanmıştır. Öğretmenlerin çok büyük bir kısmı GDO ürünlerinin çocukların beslenmesi üzerinde olumsuz etkisi olduğu yönünde görüş bildirmiştir. Çocuklar üzerinde hormonal bozukluklar yaratarak büyüme ve gelişmeyi olumsuz yönde etkilemesi başta olmak üzere erken ergenlik dönemine girmelerine neden olur. Hastalıklara karşı dirençlerini zayıflatarak, bünyelerini hassalaştırır ve dolayısıyla da kanser, alerjik ve en önemlisi obezite gibi kronik hastalıklara kapı aralar şeklinde görüşlerini belirtmişlerdir.

Tablo 7. Satın Alınan Ürünlerin İçeriğinde GDO Bakımından Kontrol Etmelerine İlişkin Fen Bilimleri Öğretmenlerinden Elde Edilen Veriler 
Tablo 7'de görüldüğü üzere öğretmenlerin satın alma işlemine gerçekleştirirken ürünlerin GDO'lu ürünler olduğuna ve olmadığına dair görüşleri alındığında “Ürün Kontrolünün Sağlanması" teması oluşturulmuştur. Öğretmenlerin cevapları incelendiğinde yarısının ürün etiketine bakarken diğer yarısının bakmadığını görülür. Ayrıca öğretmenler, bu ürünlerin kontrolünü sağlasalar bile etiketten bunu pek anlayamadıklarını ve sebze-meyvelerde buna karar vermelerinin zor olduğunu da belirtmişlerdir.

Tablo 8. Satılan Ürünlerin Etiketlerinde GDO Olup-Olmadığının Belirtilme Durumuna İlişkin Fen Bilimleri Öğretmenlerinden Elde Edilen Veriler

\begin{tabular}{|c|c|c|}
\hline TEMA & KOD & FREKANS \\
\hline & Ürünlerin etiketlerinde belirtilmez. & 13 \\
\hline \multirow[t]{2}{*}{ BELIRTME DURUMU } & Ürünlerin etiketlerinde belirtilir. & 3 \\
\hline & Bu konuda yeterli bilgim yok. & 3 \\
\hline \multirow{3}{*}{ BELİRTILME BİÇIMİ } & Koruyucu vardır ibaresi yer alır. & 1 \\
\hline & E-125 kodlu ürünlerdir. & 1 \\
\hline & Organik olup-olmadığı yazar. & 1 \\
\hline \multirow{2}{*}{\multicolumn{3}{|c|}{$\begin{array}{l}\text { Tablo 8'de görüldüğü üzere öğretmenlerin, satışa sunulan ürünlerin etiketlerinde GDO ürünü olup } \\
\text { olmadığına dair, belirtilme durumlarına yönelik görüşleri "Belirtme Durumu" ve "Belirtme } \\
\text { Biçimi" olmak üzere iki tema altında toplanmıştır. Öğretmnlerin yarısı ürün etiketlerinde } \\
\text { belirtilmediğini düşünürken çok az bir kısmı belirtildiği düşüncesinde olduğunu belirtmiştir. Yine } \\
\text { aynı şekilde bir kısmınında bu konu hakkında bilgi sahibi olmadığı görülmektedir. Etiketler de bu } \\
\text { durumu pek anlamayan bireylerin de organik ibaresine, e koduna veya koruyucu ibresine göre } \\
\text { karar verdiğini belirtmiştir. } \\
\text { Tablo 9. Türkiye'de GDO'lu Ürün Üretiminin Serbest Olma Durumuna İlişkin Fen Bilimleri Öğretmenlerinin } \\
\text { Görüşleri }\end{array}$}} \\
\hline & & \\
\hline TEMA & KOD & FREKANS \\
\hline & ürünlerin üretimi ülkemizde serbesttir. & 18 \\
\hline ÜRETIM İZNİ & da yeteri kadar bilgiye sahip değilim. & 3 \\
\hline
\end{tabular}


Tablo 9'da görüldüğü üzere öğretmenlerin GDO'lu ürünlerin ülkemizde serbestlik durumlarındaki görüşleri alındığında çoğu kişinin ülkemizde serbest olduğunu belirtmiş olsa da az bir kısmının bu konuda yeterli bilgisi olmadığını belirtmiştir.

\section{Tartışma ve Sonuç}

$\mathrm{Bu}$ araştırmada fen bilimleri öğretmenlerinin genetiği değiştirilmiş organizmalar (GDO) hakkındaki görüşlerinin belirlenmesi amaçlanmıştır. Bu doğrultuda yapılan çalışma sonucunda fen bilimleri öğretmenlerinin genetiği değiştirilmiş ürünlere yönelik görüşleri, açık uçlu sorulardan oluşan ölçme aracı kullanılarak belirlenmeye çalışılmıştır. Gerçekleştirdiğimiz çalışmada fen bilimleri öğretmenlerinin GDO'lu ürünün tanımına dair bilgileri alındığında büyük çoğunluğunun tanımı doğru olarak bildiği görülmektedir. Bu konuda üniversite öğrencileri üzerinde yapılmış olan bir çalışmada da öğrencilerin önemli bir kısmının $(\% 82,1)$ GDO'lu ürünün tanımını doğru bildikleri ve aynı şekilde bu bilincin bilimsel bir bilgi birikimine dayanmamış olması araştırmamızla örtüşür niteliktedir [23]. Bu kapsamda araştırmamızla benzer olan fen ve teknoloji öğretmen adaylarına uygulanan bir çalışmada; adayların GDO'lu besinler hakkında belirli bir bilgi birikimine sahip oldukları söylenebilir sonucuna varılması aynı şekilde araştırmamızın bulgularıyla paralellik göstermektedir [24]. Bu durumların ortaya çıkmasında öğretmenlerin üçüncü sınıfın ikinci döneminde 'Genetik ve Biyoteknoloji' dersinin, dördüncü sınıfın ilk döneminde ise 'Biyolojide Özel Konular' gibi dersleri eğitim süreçlerinde görmüş olmalarından kaynaklanıyor olabileceği düşünülmektedir. Araştırmamızda öğretmenlerin GDO’lu ürünlerin neler olabileceğine dair görüşleri alındığında öğretmenlerin büyük çoğunluğunun sebze ve meyve ürünlerinin genetiği değiştirilmiş ürünler olduğu yönünde görüş bildirdiği görülmüştür. Aynı şekilde 8.sınıf öğrencileri üzerinde yapılmış olan araştırmadan elde edilen bulgularda öğrencilerinin çoğunun sebze ve meyveler başta olmak üzere domates, misır, biber gibi besinlerin olduğu yönünde görüş belirtmiş olmaları bulgularımızla örtüşür [10]. Öğretmenlerin GDO'lu ürünlerin zararlı olabileceğine dair görüşleri incelendiğinde neredeyse tümünün zararlı olduğunu belirtmişlerdir. Çalışma grubundaki öğretmenler, genetiği değiştirilmiş olan ürünlerin insan sağlığı başta olmak üzere diğer canlıların sağlığını olumsuz yönde etkilediğini ve ekosisteme zarar vereceğini düşünmektedirler. Diğer taraftan bir kişinin yararlı olduğunu belirtmesiyle beraber bir kişi ise kararsız olduğunu dile getirmiştir. Öğretmenler, GDO'lu ürünleri sağlığa zarar veren riskli uygulamalar olarak algıladıklarını göstermektedir. Buradan hareketle fen bilimleri öğretmenlerinin GDO'lara ilişkin görüşlerinin olumsuz yönde olduğu söylenebilir. Liretaürü incelediğimizde benzer şekilde [25] çalışmalarında 8. sınıf öğrencilerinin düşüncelerinin GDO'yu yararlı olarak bulmadıklarını sonucu araştırmamızın verileriyle uyumluluk göstermektedir. Buna ek olarak GDO bilgi testinde öğrencilerin çoğunluğu GDO'lu besinlerin zararlı, kanser vb. hastalık yapıcı ya da kimyasal olduğunu düşündüklerini görülmüştür. Bu da çalışmamızdaki çocuk beslenmesinin sağlık üzerine hormonal etki yaratarak erken ergenliğe kapı aralaması, kansere ve obeziteye yol açması, hastalık yapması gibi öğretmen görüşleriyle de uyumludur. Buna ek olarak [26] çalışmasında öğrencilerin bu konu hakkında olumsuz düşüncelere sahip olduğu sonucuna ulaşmış olması, çalışmamızın sonuçlarını destekler niteliktedir. Fen bilgisi öğretmen adaylarının genetiği değiştirilmiş organizmalar (GDO) ile ilgili algılarının belirlenmesine yönelik gerçekleştirilen araştırmada [27] adaylarının ortaya atmış oldukları metaforlarda GDO'ların sağlık açısından zararlı olmaları algısının var olduğu sonucuna ulaşmaları elde etmiş olduğumuz öğretmenleri GDO'ları sağlığa zararlı olarak görmektedir sonucumuzu bir kez daha vurgular. Ayrıca alanyazında mevcut [13] tarafindan sınıf öğretmeni 
adaylarına yönelik gerçekleştirilen başka bir araştırmanın bulgularıyla ve diğer GDO'lara yönelik tutumların olumsuz olduğunu gösteren araştırma bulgularıyla da paralellik göstermektedir $[28,29]$.Öğretmenlerin satın alınan ürünlerde yer alan etiket üzerinde ürünün GDO'lu olup olmamasına dair kontrolünün sağlanmasına ilişkin görüşleri alındığında öğretmenlerin büyük çoğunluğu bakıp kontrol ettiklerini söylerken diğerleri bakmadıklarını söylemiştir. Öte yandan bir kısmının da bazen kontrol etmiş olsalar da çoğu zaman pek anlamadıklarını belirtmişlerdir. Buradan hareketle öğretmenlerin bu konuda gerekli bilgilendirmenin yapılmasının gerekliliği göz ardı edilmemelidir. Çalışma grunun büyük çoğunluğu, bu durumun etiketlerde belirtilmediğini savunurken bir kısmı koruyucu madde ve E kodu içeriklere baktıklarını belirtmişlerdir. Bu durum da yine aynı şekilde bu konuda eğitim verilmesi gerekliliğini desteklemektedir.

Sonuç olarak fen bilimlerinde sosyobilimsel bir konu olan "GDO" son derece önem taşımaktadır. Bu doğrultuda, gerçekleştirilen araştırma ile fen bilimleri öğretmenlerinin GDO’lu ürünlere yönelik görüşleri belirlenmeye çalışılmıştır. Fen bilimleri öğretmenlerinin GDO gibi sosyobilimsel konularda sahip oldukları bilgi birikimleri son derece önemlidir. Bu konuda genetiği değiştirilmiş organizmalarla ilgili görüşlerinin gelişiminde okul dışı öğrenme ortamlarının oluşturulması [11] ve bilimsel tartışma destekli öğretimin [26] etkili olduğunu tespit etmiştir. Fen bilimleri öğretmenlerinin GDO’lu ürünler konusunda önemi düşünüldüğünde, daha bilgili ve bilinçli yetişebilmeleri adına, eğitim müfredatlarında özellikle GDO içerğine dönük derslere daha fazla yer verilmelidir. Çeşitli amaçlarla düzenlenecek eğitim programları ve konferanslar gibi faaliyetlerle genç nesli yetiştiren öğretmenlerin, bu konuyla ilgili bilgi eksiklikleri giderilmeli ve doğru bilgilenmeleri sağlanmalıdır.

\section{Kaynakça}

[1]Yıldız, S.T. Ve Mazak, O. (2011). Ege Üniversitesi Öğrencilerinin Organik Ürün Ve Gdo'suz Ürün Bilinci Ve Geleceğe Dönük Tüketim Potansiyelinin Belirlenmesi (Yayımlanmamış Lisans Tezi). Ege Üniversitesi, Ziraat Fakültesi, Tarım Ekonomisi Bölümü, 48, İzmir.

[2]Kaynar, P. (2009). Genetik Olarak Değiştirilmiş Organizmalar (Gdo)'A Genel Bir Bakış. Türk Hijyen Ve Deneysel Biyoloji Dergisi 66(4): 177-185.

[4]Sadler, T. D., \& Zeidler, D. L. (2009). Scientific Literacy, P1sa, And Socio-Scientific Discourse: Assessment For Progressive Aims Of Science Education. Journal Of Research İn Science Teaching, 46(8), 909-921.

[5]Millî Eğitim Bakanlığı. (2013). İlköğretim Kurumları Fen Bilimler Dersi (3, 4, 5, 6, 7 Ve 8. Sınıflar) Öğretim Programı. Ankara: Devlet Kitapları Basım Evi.

[6]Klosterman, M. L., \& Sadler, T. D. (2010). Multi-Level Assessment Of Scientific Content Knowledge Gains Associated With Socio-Scientific İssues-Based İnstruction. International Journal Of Science Education, 32(8), 1017-1043.

[7]Albe, V. (2008). When Scientific Knowledge, Daily Life Experience, Epistemological And Social Considerations İntersect: Students Argumentation İn Group Discussions On A Socio-Scientific İssue. Research İn Science Education, 38, 67-90.Analysis (Second Edition). Thousand Oaks, Ca: Sage Publications, Inc.

[8]Lee, M. K., \& Erdogan, I. (2007). The Effect Of Science-Technology-Society Teaching On Students' Attitudes Toward Science And Certain Aspects Of Creativity. International Journal Of Science Education, 29(11), 1315-1327.Ltd.

[9]Gürkan, G. (2013). Fen Bilgisi Öğretmen Adayları Ve Öğretmenlerinin Biyoteknoloji Ve Genetik Mühendisliği Bilgi Düzeylerinin Çeşitli Değişkenler Açısından Karşılaştırılması. Yayımlanmamış Yüksek Lisans Tezi. Malatya: İnönü Üniversitesi Eğitim Bilimleri 
[10]Çinici, A, Özden, M , Akgün, A , Gülmez, H , Demirtaş, F . (2014). 8. Sinıf Öğrencilerinin Genetiği Değiştirilmiş Organizmalar (Gdo) Hakkındaki Bilgi Düzeyleri Ve Biyoteknolojiye Yönelik Tutumlarının İncelenmesi. Adıyaman Üniversitesi Fen Bilimleri Dergisi, 3 (2), 94-115.

[11]Yavuz Topaloğlu, M , Balkan Kıyıcı, F . (2018). Okul Dışı Öğrenme Ortamlarında Yürütülen Etkinliklerin Öğrencilerin Sosyobilimsel Konulara İlişkin Görüşlerine Etkisi: Organ Bağışı Ve Gdo. EUluslararası Eğitim Araştırmaları Dergisi, 9 (1), 36-50.

[12]Ertaş Karaaslan, Z. (2017). Fen Alanları Öğretmen Adaylarının Genetiği Değiştirilmiş Organizmalara (Gdo) İlişkin Metaforları Ve Görsel İmajları. Yayımlanmamış Yüksek Lisans Tezi. Diyarbakır: Dicle Üniversitesi Eğitim Bilimleri

[13]Uzunkol, E. (2012). Sınıf Öğretmeni Adaylarının Genetiği Değiştirilmiş Organizmalara (Gdo) İlişkin Algılarının Metaforlar Aracılığıyla Analizi. Eğitim Ve Öğretim Araştırmaları Dergisi, 1(4), 94-101.

[14]Karasar, N. (2016). Bilimsel Araştırma Yöntemi., Nobel Akademik Yayıncılık, Ankara.

[15]Creswell, J. W. (2008). Educational Research: Planning, Conducting, And Evaluating

[16]Fraenkel, J. R., Wallen, N. E., \& Hyun, H. H. (2012). How To Design And Evaluate Research In Education (8th Ed.). New York: Mc Graw Hill.

[17]Glazar, S. A., Vrtacnik, M. (1992). Misconception Of Chemical Concepts, Kemija V Soli, Slovene. Journal Of Chemical Education, (Special Issue) 5, 28-31.

[18]Patton, M. Q. (2014). Qualitative Research \& Evaluation Methods; Integrating Theory And Practice, Fourth Edition, Utilization-Focused Evaluation, Saint Paul, Mn

[19]Yıldırım, A. \& Şimşek, H. (2011). Sosyal Bilimlerde Nitel Araştırma Yöntemleri. Ankara: Seçkin Yayıncilik.

[20]Erişti,S.D.(2014). Uluslar Arası Erasmus Programı Çerçevesinde Türkiye'ye Gelen Sanat Ve Tasarım Öğrencilerinin Türk Kültürü Algıları. Anadolu Journal Of Eductional Sciences International,4(2),82-107. [21]Merriam,S.B.(2013). Nitel Araştırma: Desen Ve Uygulama İçin Bir Rehber. Ankara: Nobel Yayınları [22]Miles, M, B.,Ve Huberman, A. M. (1994). Qualitative Data Analysis: An Expanded Sourcebook. (2nd Ed). Thousand Oaks, Ca: Sage.Quantitative And Qualitative Research (Third Edition). New 1jersey: Pearson Education Modified Foods. Appetite, 39, 9-24.

[23]Çiftçi, K , Terin, M . (2018). Üniversite Öğrencilerinin Genetiği Değiştirilmiş Ürünler Konusundaki Bilgi Düzeyleri: Ege Üniversitesi Örneği. Uluslararası İktisadi Ve İdari İncelemeler Dergisi, (), 67-76. [24]Sönmez, A. Ve Kılınç, A. (2012). Fen Ve Teknoloji Öğretmen Adaylarının Gdo'lu Besinler Konusunun Öğretimine Yönelik Öz Yeterlilikleri: Bazı Psikometrik Faktörlerin Muhtemel Etkileri. Necatibey Eğitim Fakültesi Elektronik Fen Ve Matematik Eğitimi Dergisi, 6(2), 49-76

[25]B. Demir Ve E. Düzleyen, İlköğretim 8. Sınıf Öğrencilerinin Gdo Bilgi Düzeylerinin İncelenmesi, X. Ulusal Fen Bilimleri Ve Matematik Eğitimi Kongresi (X. Ufbmek), 27-30 Haziran, Niğde, 2012.

[26]Gülhan, F. (2012). Sosyo-Bilimsel Konularda Bilimsel Tartışmanın 8. Sınıf Öğrencilerinin Fen Okuryazarlığı, Bilimsel Tartışmaya Eğilim, Karar Verme Becerileri Ve Bilim-Toplum Sorunlarına Duyarlılıklarına Etkisinin Araştııılması. (Yayınlanmamış Yüksek Lisans Tezi).Marmara Üniversitesi, İstanbul.

[27]Kışoğlu, M , Keleş, Ö . (2018). Fen Bilgisi Öğretmen Adaylarının Genetiği Değiştirilmiş Organizmalar (Gdo) İle İlgili Algılarının Belirlenmesi. Abant İzzet Baysal Üniversitesi Eğitim Fakültesi Dergisi, 18 (4), 2123-2147.

[28]Magnusson, M.K. Ve Hursti, U.-K.K. (2002). Consumer Attitudes Towards Genetically Modified Foods. Appetite, 39, 9-24. 